Article

\title{
Expenditure Decentralization: Does It Make Us Happier? An Empirical Analysis Using a Panel of Countries
}

\author{
Leonardo E. Letelier-S ${ }^{1}$ and José L. Sáez-Lozano ${ }^{2, *}$ \\ 1 Institute of Public Affairs, University of Chile, 8320208 Santiago, Región Metropolitana, Chile; \\ lletelier@iap.uchile.cl \\ 2 Department of International and Spanish Economics, Faculty of Economics and Business Sciences, \\ Office B-301, Campus Universitario de La Cartuja, 18071 Granada, Spain \\ * Correspondence: josaez@ugr.es
}

Received: 3 July 2020; Accepted: 30 August 2020; Published: 4 September 2020

\begin{abstract}
This paper analyzes whether fiscal decentralization of education, health, housing, social protection, recreation, culture and religion, public order and safety, and transportation have a significant effect on individual well-being. The empirical analysis is based on a non-linear hierarchical model that combines individual data (level 1) with country-level data (level 2). We match 89,584 observations from the World Value Service and the European Value Service (various years) with the average value of data recorded for 30 countries by the Government Financial Statistics (IMF). While fiscal decentralization in education and housing appears to have a negative effect on well-being, this effect is positive in the cases of health and culture and recreation. We interpret this as evidence in favor of a "selective" decentralization approach.
\end{abstract}

Keywords: decentralization; happiness; subjective well-being; public policy

\section{Introduction}

Standard economic theory suggests that decentralization may improve the quality of public service delivery. On one hand, sub-national governments are assumed to be better informed on citizens' preferences [1]. On the other, decentralization entails a different institutional order, in which the political game is expected to be more accountable to people [2-4]. Theoretically, it has been argued that decentralization in general, and fiscal decentralization (FD) in particular may contribute to greater economic growth and more public efficiency. While its link to growth is still controversial [5-7], the effect on public sector efficiency is the subject of an intense debate in which some areas of government seem to be particularly sensitive to decentralization [8]. Some caveats on decentralization comprise the excess proximity between private and public interests, the weakness of local bureaucracy, the danger of corruption and elite capture, and the lack of scale economies among others [9-12]. Though some studies have been carried out on the effect of decentralization on Subjective Well Being SWB [13-23], the influence of function-specific types of decentralization is still unattended. We address said missing challenge by estimating the effect of seven alternative expenditure-based fiscal decentralization definitions. Two hypotheses are put forward. First, we hypothesize that benefits from FD are contingent upon the area of government in question, which implies that all across the board decentralization policies are no good. Second, the effect of FD on standardized policy outputs are not necessarily in line with the corresponding effect on SWB.

Given that decentralization in general, and FD in particular, is a complex phenomenon whose impact is expected to differ across specific areas of public management [24-26], this paper states that its effect on SWB depends on the specific area being decentralized. This effect is identified through a 
multilevel ordinal logit model with a random intercept and a set of fixed effects [27-29]. State functions being examined are education, health, housing, social protection, recreation culture and religion, public order and safety, and transportation. We match 89,584 observations from the World Value Service and the European Value Service (various years) with 30 country-level records on national and sub-national expenditure taken from the Government Financial Statistics (IMF). We use the country average of available series based on the 1986 IMF recording methodology. Our estimations show that decentralization in the areas of recreation, culture and religion, and health has a positive effect on SWB; whereas decentralization on education and housing has a negative impact.

The theory on SWB dates back to the 1970s and 1980s [30-38]. This literature intends to explain life satisfaction through the lens of ordinal utility. The works by Ferrer-i-Carbonell and Frijters [39] have contributed significantly to advancing this theory in the spheres of personal health, family income, working conditions, and leisure and free time among others. As far as the economics of happiness is concerned, Frey and Stutzer $[18,19]$ differentiate three categories of exogenous factors that determine SWB: (i) personality and demographic factors (age, sex, marital status, level of education, ideology, religion, etc.); (ii) micro and macroeconomic factors (level of income, unemployment, inflation, etc.); and (iii) the institutional context (democratic state, federalism, decentralization, etc.). By taking the case of Switzerland, they concluded that institutional factors, such as government initiatives, referendums, and local autonomy have a significant and positive effect on the satisfaction of the Swiss. A similar study was conducted by Diaz-Serrano and Rodríguez-Pose [15], who extended the analysis to a set of European countries to explore how different powers and resources of regional and local European governments improve the level of individual satisfaction. Bjornskov et al. [13] made use of a more extensive database that included 60,000 individual observations from 66 countries and found that expenditure decentralization does not have a significant impact on happiness. Sujarwoto and Tampubolon [22] found that in the case of Indonesia, FD increases happiness, but political decentralization does not. Further analysis and similar conclusions on the role of institutions can be found in Frey and Stutzer [19], Stutzer and Lalive [40], Bjornskov, Drehe and Fischer [13,41], Diaz-Serrano and Rodríguez-Pose [15], Voigt and Blume [23], and Rodriguez-Pose and Tselios [21]. Evidence on the effect of ideology and other characteristics of the Welfare State has been provided by Radcliff [42] and Veenhoven [43]. Said evidence shows that in affluent countries, political and individual liberty have a positive effect on SWB. As for less affluent countries, economic institutions and courts appear to have a greater influence.

The remaining of this paper is organized as follows. The presentation of hypotheses, the empirical methodology and data description are the subject of Section 2. Results are reported in Section 3. Section 4 discusses the findings and Section 5 presents conclusions.

\section{Hypotheses, Methodology, and Data}

\subsection{Empirical Framework}

Happiness $S_{i j}^{*}$ is assumed to be a continuous and latent variable that reflects the level of SWB. $S_{i j}^{*}$ is determined by two sets of explanatory variables: (i) the individual $X_{i j}$, which represents the characteristics of individuals $i$ in the country $j$; and (ii) the country (grouped variable) $Z_{j}$, which represents the country level, whose effect is measured by the degree of expenditure FD.

We define the following linear relationship between the endogenous and the explanatory variables as:

$$
S_{i j}^{*}=\beta X_{i j}+\lambda Z_{j}+\varepsilon_{i j}
$$

where $\beta$ and $\lambda$ are the coefficients to be estimated and $\varepsilon_{i j}$ the error term. Given that happiness is an unobservable variable, we define it through the level of individual satisfaction $S_{i j}$. The relationship between $S_{i j}^{*}$ and $S_{i j}$, for the $m$ category of $S_{i j}$, is:

$$
S_{i j}=m \text { if } k_{m-1} \leq S_{i j}^{*}<k_{m} ; m=1,2, \ldots, M
$$


where $k_{m-1} \ldots k_{m}$ stand for the threshold values. The accumulated probability of the $m$ category of $S_{i j}$, is:

$$
\operatorname{Pr}\left(S_{i j}>m \mid X_{i j}, Z_{j}\right)
$$

We assume that individuals $(i)$ are nested in the countries $(j)$. Therefore, $\operatorname{VAR}\left(\varepsilon_{i j}\right)$ is expected to differ across $j$ groups. This implies that observations are conditionally independent, which relaxes the homoscedasticity condition. Additionally, we assume that the influence of the predictor variable is fixed in two levels of analysis and that a random term $U_{0 m j}$ exists, that captures the inter-group differences.

Based on Equation (3), a multilevel ordinal logit model with a random intercept and $m$ categories of fixed effects $\left(S_{i j}\right)$ (Based on the endogenous variable $S_{i j}$, an ordinal logit or probit model can be specified. Since we assume fixed effects in the explanatory individual variables, we reject the option of an ordinal probit, as this produces inconsistent estimations.) can be deduced (4). There are three reasons for not specifying a multilevel ordinal logit model with an intercept and a random slope for $X_{i j}$ : (i) the theory does not justify that the effect of $X_{i j}$ differs across $j$ units due to unobservable factors; (ii) differential effects of grouped $j X_{i j}$ are explained by $Z_{j}$ variables; and (iii) the inclusion of interaction terms between $X_{i j}$ and $Z_{j}$ is not theoretically sound in this case. See Appendix A for details.

$$
\ln \left(\frac{\exp \left(\beta X_{i j}+\lambda Z_{j}+\varepsilon_{i j}\right)}{1-\exp \left(\beta X_{i j}+\lambda Z_{j}+\varepsilon_{i j}\right)}\right)=\beta_{00 j}+\sum_{l=1}^{L} \beta_{l m j} X_{l i j}+\sum_{r=1}^{R} \lambda_{r m j} Z_{r j}+U_{0 m j}+\varepsilon_{m i j}
$$

where $\beta_{00 j}$ is the constant term, $\beta_{l m j}$ measures the effect of $X_{i j}$ individual variables (level 1$), \lambda_{r m j}$ is the set of associated coefficients of $Z_{s j}$ variables (level 2), and $U_{0 m j}$ is the country-level random effect.

\subsection{Hypotheses}

Based on the literature above, costs and benefits of FD are expected to differ across areas of government. For example, some areas may require a significant degree of local information, so that decentralization is likely to improve the quality of local provision. While this should not be true in all cases, the loss of economies of scale, the danger of elite capture, and the potential for inter-jurisdictional externalities among other caveats may hinder these benefits. In view of this, the following hypothesis is proposed:

Hypothesis 1. Since costs and benefits from FD are expected to differ across specific areas of government, the effect of FD on SWB should be contingent upon the government function in question.

While individuals are expected to identify the aforementioned benefits and costs, their judgment is assumed to assign subjective weights to the various dimensions of government performance within specific areas of government. It follows that the effect of FD on SWB may differ from this same effect being measured over specific standardized measurements of the government's performance.

Hypothesis 2. Individuals assign subjective weights to specific dimensions of the government's performance. Since different areas of government are assumed to comprise numerous specific functions, it follows that the effect of FD on SWB may differ from this same effect over standardized measurements of government performance.

\subsection{Methodology}

In order to estimate Model (4), we use a maximum likelihood method (ML) based on an adaptation of the Gauss quadrature proposed by Rabe-Hesketh, Skrondal, and Pickles [28]. To maximize the likelihood function, a Newton-Raphson algorithm is adopted (see the Appendix A). We also estimate two additional models. A logit ordinal model with a random intercept and fixed effects, and an ordinal logit with a random intercept. See Appendix A for details. 


\subsection{The Data}

The database of this research is based on three sources. They are the World Value Survey (WVS), the European Value Survey (EVS), and the Government Financial Statistics (GFS) from the IMF. The WVS is a world-level research project that analyzes people's values and beliefs. It provides surveys with representative national samples, in which a standardized questionnaire is used (http: //www.worldvaluessurvey.org/wvs.jsp). The EVS is also a global research project that covers European countries only. Just like the WVS, it provides detailed information on the ideas, beliefs, preferences, attitudes, values, and opinions (http://www.europeanvaluesstudy.eu/). Until now, six waves of the WVS and EVS have been carried out. They are wave 1 (1981-1984), wave 2 (1989-1993), wave 3 (1994-1999), wave 4 (1999-2004), wave 5 (2005-2007), and wave 6 (2008-2010). The GFS comprise a database produced by the IMF that provides fiscal and budgetary information by country, of which only 44 report sub-national expenditure (revenue) data. Table 1 presents a summary of the sources and types of variables being used. Information on reported years by country, sources, and available waves of surveys is presented in Table 2. Individual-level observations are 89,584. Given that not all countries from the IMF data set are represented in the WVS and the EVS, some countries are not included in the estimations (Table 2).

Table 1. Variable, measurement, and source.

\begin{tabular}{|c|c|c|c|}
\hline Variable & Definition & Measurement & Source \\
\hline \multicolumn{4}{|c|}{ Endogenous } \\
\hline S & Level of satisfaction & $\begin{array}{l}\text { Nothing satisfaction } \\
\text { level }(0) \text {, somewhat } \\
\text { satisfied (1), quite } \\
\text { satisfied (2), and very } \\
\text { satisfied (3) }\end{array}$ & $\begin{array}{c}\text { World Values Survey } \\
\text { (WVS)/European Values } \\
\text { Survey (EVS) }\end{array}$ \\
\hline \multicolumn{4}{|c|}{ Explanatory: Individual } \\
\hline INCOME & Household income & Decile & $\begin{array}{c}\text { World Values Survey } \\
\text { (WVS)/European Values } \\
\text { Survey (EVS) }\end{array}$ \\
\hline GENDER & Gender & $\begin{array}{l}\text { Dummy: men (1) and } \\
\text { others (0) }\end{array}$ & $\begin{array}{c}\text { World Values Survey } \\
\text { (WVS)/European Values } \\
\text { Survey (EVS) }\end{array}$ \\
\hline AGE & Age & Years & $\begin{array}{c}\text { World Values Survey } \\
\text { (WVS)/European Values } \\
\text { Survey (EVS) }\end{array}$ \\
\hline MARRIED-COUPLE & $\begin{array}{l}\text { Marital status: married } \\
\text { or lives as a couple }\end{array}$ & $\begin{array}{l}\text { Dummy: married or } \\
\text { live-in couple }(1) \text { and } \\
\text { other states }(0)\end{array}$ & $\begin{array}{c}\text { World Values Survey } \\
\text { (WVS)/European Values } \\
\text { Survey (EVS) }\end{array}$ \\
\hline $\begin{array}{l}\text { PRIMARYEDU } \\
\text { CATIONPRIMARY } \\
\text { EDUCATION }\end{array}$ & $\begin{array}{l}\text { Level of studies: primary } \\
\text { education }\end{array}$ & $\begin{array}{l}\text { Dummy: primary } \\
\text { studies (1) and other } \\
\text { levels of studies }(0)\end{array}$ & $\begin{array}{c}\text { World Values Survey } \\
\text { (WVS)/European Values } \\
\text { Survey (EVS) }\end{array}$ \\
\hline $\begin{array}{l}\text { SECONDARY } \\
\text { EDUCATION }\end{array}$ & $\begin{array}{l}\text { Level of studies: } \\
\text { secondary education }\end{array}$ & $\begin{array}{l}\text { Dummy: secondary } \\
\text { studies (1) and other } \\
\text { levels of studies (0) }\end{array}$ & $\begin{array}{c}\text { World Values Survey } \\
\text { (WVS)/European Values } \\
\text { Survey (EVS) }\end{array}$ \\
\hline HIGHER EDUCATION & $\begin{array}{l}\text { Level of studies: higher } \\
\text { education }\end{array}$ & $\begin{array}{c}\text { Dummy: higher } \\
\text { education (1) and other } \\
\text { levels of studies }(0)\end{array}$ & $\begin{array}{c}\text { World Values Survey } \\
\text { (WVS)/European Values } \\
\text { Survey (EVS) }\end{array}$ \\
\hline
\end{tabular}


Table 1. Cont.

\begin{tabular}{|c|c|c|c|}
\hline Variable & Definition & Measurement & Source \\
\hline CHILDREN & Number of children & $\begin{array}{l}\text { Children number: } 0 \text { to } 8 \\
\text { or more children }\end{array}$ & $\begin{array}{c}\text { World Values Survey } \\
\text { (WVS)/European Values } \\
\text { Survey (EVS) }\end{array}$ \\
\hline MUSLIM & Muslim religion & $\begin{array}{l}\text { Dummy: Muslim (1) and } \\
\text { other religion (0) }\end{array}$ & $\begin{array}{c}\text { World Values Survey } \\
\text { (WVS)/European Values } \\
\text { Survey (EVS) }\end{array}$ \\
\hline CATHOLIC & Catholic religion & $\begin{array}{l}\text { Dummy: Catholic (1) } \\
\text { and other religion (0) }\end{array}$ & $\begin{array}{c}\text { World Values Survey } \\
\text { (WVS)/European Values } \\
\text { Survey (EVS) }\end{array}$ \\
\hline PROTESTANT & Protestant religion & $\begin{array}{l}\text { Dummy: Protestant (1) } \\
\text { and other religion }(0)\end{array}$ & $\begin{array}{c}\text { World Values Survey } \\
\text { (WVS)/European Values } \\
\text { Survey (EVS) }\end{array}$ \\
\hline ORTHODOX & Orthodox religion & $\begin{array}{l}\text { Dummy: Orthodox (1) } \\
\text { and other religion (0) }\end{array}$ & $\begin{array}{c}\text { World Values Survey } \\
\text { (WVS)/European Values } \\
\text { Survey (EVS) }\end{array}$ \\
\hline JEWISH & Jewish religion & $\begin{array}{l}\text { Dummy: Jewish }(1) \text { and } \\
\text { other religion }(0)\end{array}$ & $\begin{array}{c}\text { World Values Survey } \\
\text { (WVS)/European Values } \\
\text { Survey (EVS) }\end{array}$ \\
\hline IDEOLOGY & Ideology & $\begin{array}{c}\text { Discrete: left (0) and } \\
\text { right (9) }\end{array}$ & $\begin{array}{c}\text { World Values Survey } \\
\text { (WVS)/European Values } \\
\text { Survey (EVS) }\end{array}$ \\
\hline UNEMPLOYED & Labor status & $\begin{array}{l}\text { Dummy: unemployed } \\
\text { (1) and others (0) }\end{array}$ & $\begin{array}{c}\text { World Values Survey } \\
\text { (WVS)/European Values } \\
\text { Survey (EVS) }\end{array}$ \\
\hline \multicolumn{4}{|c|}{ Explanatory: National (by country) } \\
\hline FDED & $\begin{array}{l}\text { Fiscal decentralization } \\
\text { on education }\end{array}$ & $\begin{array}{l}\text { Education expenditure of } \\
\text { state and local } \\
\text { government/local, state, } \\
\text { and central education } \\
\text { expenditure }\end{array}$ & $\begin{array}{c}\text { IMF Government } \\
\text { Financial Statistics (GFS) }\end{array}$ \\
\hline FDHE & $\begin{array}{l}\text { Fiscal decentralization } \\
\text { on health }\end{array}$ & $\begin{array}{l}\text { Health expenditure of } \\
\text { state and local } \\
\text { government/local, state, } \\
\text { and central health } \\
\text { expenditure }\end{array}$ & $\begin{array}{c}\text { IMF Government } \\
\text { Financial Statistics (GFS) }\end{array}$ \\
\hline FDHO & $\begin{array}{l}\text { Fiscal decentralization } \\
\text { on housing }\end{array}$ & $\begin{array}{l}\text { Housing expenditure of } \\
\text { state and local } \\
\text { government/local, state, } \\
\text { and central housing } \\
\text { expenditure }\end{array}$ & $\begin{array}{c}\text { IMF Government } \\
\text { Financial Statistics (GFS) }\end{array}$ \\
\hline FDSP & $\begin{array}{l}\text { Fiscal decentralization } \\
\text { on social protection }\end{array}$ & $\begin{array}{l}\text { Social protection } \\
\text { expenditure of state and } \\
\text { local government/local, } \\
\text { state, and central social } \\
\text { protection expenditure }\end{array}$ & $\begin{array}{c}\text { IMF Government } \\
\text { Financial Statistics (GFS) }\end{array}$ \\
\hline FDRCR & $\begin{array}{c}\text { Fiscal decentralization } \\
\text { on recreation, culture } \\
\text { and religion }\end{array}$ & $\begin{array}{l}\text { Recreation, culture and } \\
\text { religion expenditure of } \\
\text { state and local } \\
\text { government/local, state, } \\
\text { and central recreation, } \\
\text { culture and religion } \\
\text { expenditure }\end{array}$ & $\begin{array}{c}\text { IMF Government } \\
\text { Financial Statistics (GFS) }\end{array}$ \\
\hline
\end{tabular}


Table 1. Cont.

\begin{tabular}{cccc}
\hline Variable & Definition & Measurement & Source \\
\hline FDPOS & $\begin{array}{c}\text { Public order and safety } \\
\text { expenditure of state and } \\
\text { local government/local, } \\
\text { public order and safety } \\
\text { state, and central public } \\
\text { order and safety } \\
\text { expenditure }\end{array}$ & $\begin{array}{c}\text { IMF Government } \\
\text { Financial Statistics (GFS) }\end{array}$ \\
FDRTRANS & $\begin{array}{c}\text { Transportation } \\
\text { expenditure of state and } \\
\text { local government/local, } \\
\text { state, and central } \\
\text { transportation } \\
\text { expenditure }\end{array}$ & Financial Statistics (GFS) \\
& on transportation & IMF Government \\
& & & \\
\hline
\end{tabular}

Table 2. Countries, time series of the functions of expenses decentralized, and waves of the World Value Survey (WVS)/European Value Survey (EVS).

\begin{tabular}{|c|c|c|}
\hline Country & IMF Time-Span Data & Source/Wave/Year \\
\hline Albania & 1995-1998 & WVS/3/1998 \\
\hline Argentina & 1972-1999 & WVS/4/1999 \\
\hline Australia & 1972-1995 & WVS/3/1995 \\
\hline Austria & 1972-1990 & EVS/2/1990 \\
\hline Bulgaria & 1988-2006 & WVS/5/2006 \\
\hline Canada & 1979-2006 & WVS/5/2006 \\
\hline Chile & 1974-1988 & WVS/2/1990 \\
\hline Croatia & 1995-1999 & EVS/4/1999 \\
\hline Czech Republic & 1993-1999 & $\mathrm{EVS} / 4 / 1999$ \\
\hline Denmark & 1972-1999 & EVS/4/1999 \\
\hline Estonia & 1991-1999 & WVS/4/1999 \\
\hline France & 1978-1990 & WVS/2/1990 \\
\hline Germany & 1974-1990 & EVS/2/1990 \\
\hline Hungary & 1990-1999 & EVS/4/1999 \\
\hline Iceland & 1972-1990 & EVS/2/1990 \\
\hline India & 1974-2001 & WVS/4/2001 \\
\hline Iran, I. R. & 1999-2007 & WVS/5/2007 \\
\hline Ireland & 1982-1990 & EVS/2/1990 \\
\hline Latvia & 1994-1999 & EVS/4/1999 \\
\hline Lithuania & 1993-1999 & EVS/4/1999 \\
\hline Norway & 1980-1996 & WVS/3/1996 \\
\hline Poland & 1994-1999 & EVS/4/1999 \\
\hline Romania & 1990-1999 & EVS/4/1999 \\
\hline Slovakia & 1996-1999 & EVS/4/1999 \\
\hline Spain & 1995-1997 & EVS/4/1999 \\
\hline Switzerland & 1990-1996 & WVS/3/1996 \\
\hline The Netherlands & 1991-1997 & EVS/4/1999 \\
\hline Uganda & 1999-2001 & WVS/4/2001 \\
\hline United Kingdom & 1979-1998 & WVS/3/1998 \\
\hline United States & 1980-1999 & WVS/4/1999 \\
\hline
\end{tabular}


As shown in Table 2, our endogenous variable $S_{i j}$ is ordinal and has four possible values that capture individual life satisfaction. They are not at all satisfied (0), somewhat satisfied (1), quite satisfied (2), or very satisfied (3). We define the following relationship between $S_{i j}^{*}$ and $S_{i j}$ as:

$$
S_{i j}=\left\{\begin{array}{lll}
0 & \text { si } & S^{*} \leq \kappa_{0} \\
1 & \text { si } & \kappa_{0}<S^{*} \leq \kappa_{1} \\
& & \\
2 & \text { si } & \kappa_{1}<S^{*} \leq \kappa_{2} \\
3 & \text { si } & S^{*}>\kappa_{2}
\end{array}\right.
$$

A total of 22 explanatory variables have been considered. Individual variables represent major personality characteristics. They are level of income (INCOME); sex (SEX); age (AGE); marital status (MARRIED-COUPLE); levels of primary (PRIMARY EDUCATION), secondary (SECONDARY EDUCATION), and higher (HIGHER EDUCATION) education; number of children (CHILDREN); Muslim (MUSLIM), Catholic (CATHOLIC), Protestant (PROTESTANT), Orthodox (ORTHODOX), and Jewish (JEWISH) religious confessions; individual ideology (IDEOLOGY); and job status (UNEMPLOYED). Seven grouped variables measure the level of FD in education (FDED), health (FDHE), housing $(F D H O)$, social protection $(F D S P)$, recreation, culture and religion $(F D R C R)$, public order and safety (FDPOS), and transportation (FDTRANS).

$A G E$ and IDEOLOGY are continuous variables. We have defined a quadratic function for age. IDEOLOGY reflects the position on a 10 point scale from left to right. INCOME and CHILDREN are discrete variables. INCOME reflects the segment (decile) that the individual belongs to. CHILDREN indicates the number of children, with a reproof in the value equal to 8 children. Remaining individual explanatory variables are defined as follows: SEX ( 1 if male and 0 otherwise), MARRIED-COUPLE ( 1 for these who are married or live with another and 0 otherwise), PRIMARY EDUCATION (1 for these who attended primary school and 0 otherwise), SECONDARY EDUCATION ( 1 for these who have done secondary studies and 0 otherwise), HIGHER EDUCATION (1 for these who have done third level studies or higher and 0 otherwise), MUSLIM (1 for Muslim and 0 otherwise), CATHOLIC ( 1 for Catholic and 0 otherwise), PROTESTANT (1 for Protestant and 0 otherwise), ORTHODOX ( 1 for Orthodox and 0 otherwise), JEWISH ( 1 for Jewish and 0 otherwise), UNEMPLOYED (1 for unemployed and 0 otherwise).

The data for both the endogenous as well as individual-level explanatory variables were taken from the WVS and the EVS. The source is cited in Table 2, which indicates the available wave of information and the year in which the study was carried out. For most countries in the sample, we selected the wave of the WVS and EVS whose year of execution coincides with the last period of the time series on decentralized spending (GFS). Variable FD measures the share of sub-national expenditure in the general government expenditure by each of the seven government areas being analyzed. This was taken as a proxy of the area-specific sub-national fiscal involvement, which stands for the degree of local authorities' accountability and the extent of a match between local public goods provision and residents' preferences. We used the 1986 IMF recording methodology (As opposed to the "accrued based" recording initiated in 2011, the 1986 criteria is based on cash flow values. See details in; Government Finance Statistics Manual 2001 (IMF, 2001)), as it provides longer series. Each country-level FD proxy was measured as an average of all available yearly values for the country in question (Tables 2 and 3). Since not all countries in the sample exhibit data for the same time-span, this average was matched with the closest next WVS or EVS relative to the last country expenditure IMF record. We allowed a maximum of two years of gap between the IMF data and the corresponding survey. Separate FD proxies by country are estimated on education, health, housing, social protection, recreation, culture and religion, public order and safety, and transportation. 
Table 3. Descriptive statistics.

\begin{tabular}{|c|c|c|c|c|}
\hline Variables & Mean & Std. Dev. & Min. & Max. \\
\hline \multicolumn{5}{|c|}{ Individual variables } \\
\hline INCOME & 4.084 & 2.525 & 0 & 10 \\
\hline GENDER & 0.4951 & 0.500 & 0 & 1 \\
\hline AGE & 44.087 & 16.691 & 14 & 100 \\
\hline MARRIED-COUPLE & 0.670 & 0.470 & 0 & 1 \\
\hline $\begin{array}{c}\text { PRIMARY } \\
\text { EDUCATION }\end{array}$ & 0.091 & 0.290 & 0 & 1 \\
\hline $\begin{array}{l}\text { SECONDARY } \\
\text { EDUCATION }\end{array}$ & 0.203 & 0.402 & 0 & 1 \\
\hline $\begin{array}{c}\text { HIGHER } \\
\text { EDUCATION }\end{array}$ & 0.1519 & 0.359 & 0 & 1 \\
\hline CHILDREN & 1.784 & 1.5118 & 0 & 8 \\
\hline MUSLIM & 0.035 & 0.185 & 0 & 1 \\
\hline CATHOLIC & 0.373 & 0.484 & 0 & 1 \\
\hline PROTESTANT & 0.209 & 0.407 & 0 & 1 \\
\hline ORTHODOX & 0.061 & 0.239 & 0 & 1 \\
\hline JEWISH & 0.004 & 0.060 & 0 & 1 \\
\hline IDEOLOGY & 4.408 & 2.084 & 0 & 9 \\
\hline UNEMPLOYED & 0.057 & 0.233 & 0 & 1 \\
\hline \multicolumn{5}{|c|}{ National variables } \\
\hline FDED & 0.568 & 0.313 & 0 & 0.946 \\
\hline FDHE & 0.361 & 0.290 & 0 & 0.882 \\
\hline FDHO & 0.679 & 0.218 & 0.164 & 0.996 \\
\hline FDSP & 0.180 & 0.219 & 0.003 & 1 \\
\hline FDRCR & 0.670 & 0.211 & 0.205 & 1 \\
\hline FDPOS & 0.402 & 0.355 & 0 & 1 \\
\hline FDTRANS & 0.463 & 0.191 & 0.032 & 0.783 \\
\hline
\end{tabular}

\section{Results}

Table 4 presents estimations of a multilevel ordinal logit with a random intercept (Model 1), a multilevel ordinal logit with a random intercept and fixed effects, individual explanatory variables (Model 2), and an ordinal logit with a random intercept and fixed effects (Model 3). The first part of the table shows the coefficients estimated for the fixed part, that is to say, of the grouped individual explanatory variable and the values threshold $\kappa_{0}, \kappa_{1} y \kappa_{2}$. In the second section of the table, the variance of the random part is shown. In the third part, various statistics of the three models are reported.

Table 4. Multilevel ordinal logit of happiness.

\begin{tabular}{|c|c|c|}
\hline & Model 2 & Model 3 \\
\hline \multicolumn{3}{|c|}{ Fixed Part } \\
\hline \multicolumn{3}{|c|}{ Individual variables } \\
\hline INCOME & $\begin{array}{c}0.072 * * * \\
(23.77)\end{array}$ & $\begin{array}{c}0.067^{* * *} \\
(20.80)\end{array}$ \\
\hline GENDER & $\begin{array}{c}0.116^{* * *} \\
(8.53)\end{array}$ & $\begin{array}{c}0.117^{* * *} \\
(8.04)\end{array}$ \\
\hline AGE & $\begin{array}{c}-0.069 \text { *** } \\
(-27.02)\end{array}$ & $\begin{array}{c}-0.071^{\text {*** }} \\
(-26.54)\end{array}$ \\
\hline
\end{tabular}


Table 4. Cont.

\begin{tabular}{|c|c|c|c|}
\hline & Model 1 & Model 2 & Model 3 \\
\hline $\mathrm{AGE}^{2}$ & & $\begin{array}{c}0.001^{* * *} \\
(24.29)\end{array}$ & $\begin{array}{c}0.001^{* * *} \\
(23.72)\end{array}$ \\
\hline MARRIED-COUPLE & & $\begin{array}{c}0.692 * * * \\
(41.25)\end{array}$ & $\begin{array}{c}0.743^{* * *} \\
(41.80)\end{array}$ \\
\hline PRIMARY EDUCATION & & $\begin{array}{c}0.125^{* * *} \\
(5.00)\end{array}$ & $\begin{array}{c}0.127^{* * *} \\
(4.80)\end{array}$ \\
\hline SECONDARY EDUCATION & & $\begin{array}{c}0.316^{* * *} \\
(16.96)\end{array}$ & $\begin{array}{c}0.332 * * * \\
(16.63)\end{array}$ \\
\hline HIGHER EDUCATION & & $\begin{array}{c}0.420^{* * *} \\
(20.33)\end{array}$ & $\begin{array}{c}0.467^{* * *} \\
(20.86)\end{array}$ \\
\hline CHILDREN & & $\begin{array}{l}-0.004 \\
(-0.67)\end{array}$ & $\begin{array}{l}-0.001 \\
(-0.23)\end{array}$ \\
\hline MUSLIM & & $\begin{array}{l}-0.094 \\
(-1.60)\end{array}$ & $\begin{array}{l}-0.137 \\
(-1.92)\end{array}$ \\
\hline CATHOLIC & & $\begin{array}{c}0.084^{* * *} \\
(4.37)\end{array}$ & $\begin{array}{c}0.083^{* * *} \\
(4.08)\end{array}$ \\
\hline PROTESTANT & & $\begin{array}{c}0.143^{* * *} \\
(6.23)\end{array}$ & $\begin{array}{c}0.148^{* * *} \\
(6.23)\end{array}$ \\
\hline ORTHODOX & & $\begin{array}{l}0.029 \\
(0.64)\end{array}$ & $\begin{array}{l}0.008 \\
(0.18)\end{array}$ \\
\hline JEWISH & & $\begin{array}{c}-0.320 * * \\
(-2.83)\end{array}$ & $\begin{array}{c}-0.310 * * \\
(-2.65)\end{array}$ \\
\hline IDEOLOGY & & $\begin{array}{c}0.047^{* * *} \\
(14.19)\end{array}$ & $\begin{array}{c}0.051^{* * *} \\
(13.81)\end{array}$ \\
\hline UNEMPLOYED & & $\begin{array}{c}-0.518^{* * * *} \\
(-17.31)\end{array}$ & $\begin{array}{c}-0.583 * * * \\
(-18.18)\end{array}$ \\
\hline \multicolumn{4}{|c|}{ National variables } \\
\hline FDED & & & $\begin{array}{c}-1.270 * * \\
(-3.02)\end{array}$ \\
\hline FDHE & & & $\begin{array}{l}0.978 * \\
(2.29)\end{array}$ \\
\hline FDHO & & & $\begin{array}{c}-1.674^{* * *} \\
(-3.55)\end{array}$ \\
\hline FDSP & & & $\begin{array}{l}0.927 \\
(0.82)\end{array}$ \\
\hline FDRCR & & & $\begin{array}{c}3.308 * * * \\
(4.69)\end{array}$ \\
\hline FDPOS & & & $\begin{array}{l}0.315 \\
(0.63)\end{array}$ \\
\hline FDTRANS & & & $\begin{array}{l}0.765 \\
(1.07)\end{array}$ \\
\hline Constant & $\begin{array}{c}0.817 * * * \\
(0.071)\end{array}$ & $\begin{array}{c}0.855^{* * *} \\
(10.74)\end{array}$ & $\begin{array}{c}0.430 * * * \\
(7.12)\end{array}$ \\
\hline
\end{tabular}


Table 4. Cont.

\begin{tabular}{|c|c|c|c|}
\hline & Model 1 & Model 2 & Model 3 \\
\hline \multicolumn{4}{|l|}{ Fixed Part: Thresholds } \\
\hline$\kappa_{0}:$ Cutconstant & $\begin{array}{c}-4.089^{* * *} \\
(0.125)\end{array}$ & $\begin{array}{l}-4.612^{* * *} \\
(-32.44)\end{array}$ & $\begin{array}{c}-3.669^{* * *} \\
(-8.58)\end{array}$ \\
\hline$\kappa_{1}$ : Cutconstant & $\begin{array}{l}-1.759^{* * *} \\
(0.123)\end{array}$ & $\begin{array}{l}-2.213^{* * * *} \\
(-15.76)\end{array}$ & $\begin{array}{l}-1.271^{* *} \\
(-2.98)\end{array}$ \\
\hline$\kappa_{2}:$ Cutconstant & $\begin{array}{c}1.264^{* * *} \\
(0.123)\end{array}$ & $\begin{array}{l}0.914^{* * *} \\
(6.52)\end{array}$ & $\begin{array}{c}2.040 * * * \\
(4.78)\end{array}$ \\
\hline \multicolumn{4}{|c|}{ Random Part: Variances and Covariances } \\
\hline Level 2 Variance $\left(U_{0 m j}\right)^{(1)}$ & $\begin{array}{c}0.668 \\
(0.116) \\
\end{array}$ & $\begin{array}{c}0.317 \\
(0.009)\end{array}$ & $\begin{array}{c}0.185 \\
(0.052)\end{array}$ \\
\hline No. Obs. Level 1 & 89,584 & 89,584 & 79,097 \\
\hline No. Obs. Level 2 & 30 & 30 & 26 \\
\hline $\begin{array}{c}\text { No. Iteration of Adaptive } \\
\text { Quadrature } \\
\text { (Newton-Raphson) }\end{array}$ & 6 & 4 & 4 \\
\hline No. Integration Points & 16 & 16 & 16 \\
\hline Wall Clock Time & 00:00:40 & 0:49:09 & 01:52:12 \\
\hline $\begin{array}{l}\text { Intraclass Correlation } \\
\text { Coefficient (ICC): }\end{array}$ & 0.237 & 0.1286 & 0.080 \\
\hline $\begin{array}{l}-2 \text { Log Likelihood } \\
\text { Rrestricted }\end{array}$ & $172,038.8$ & $170,706.6$ & $143,481.3$ \\
\hline $\begin{array}{l}\text { Akaike Information } \\
\text { Criterion (AIC) }\end{array}$ & $172,046.8$ & $164,880.1$ & $143,535.3$ \\
\hline $\begin{array}{l}\text { Bayesian Information } \\
\text { Criterion (BIC) }\end{array}$ & $172,084.4$ & $165,067.8$ & $143,785.8$ \\
\hline
\end{tabular}

(1) The standard error is in brackets. Notes: ${ }^{* * *},{ }^{* *}$, and ${ }^{*}$ indicate significance level at $1 \%, 5 \%$, and $10 \%$, respectively. $\mathrm{Z}$ value in brackets. "Not at all happy" is the reference category.

The value of the intraclass correlation coefficient (ICC) of Model 1 shows that $23.7 \%$ of the SWB variance is explained by individual characteristics unrelated to the country of residence. The variance of the random part diminishes by more than half in Model 2, which explains why the ICC is substantially lower (0.1286). By looking at the log-likelihood ratio test, the Akaike information criterion (AIC) and the Bayesian information criterion (BIC) of both models, we conclude that Model 2 is a better option compared to Model 1.

The incorporation of national explanatory variables in Model 3 contributes to reducing the variance of the random part further, leading to a lower ICC as compared to Models 1 and 2. Once again, the likelihood ratio test, as well as the AIC and BIC values show that Model 3 is better. It must be noted that coefficients of the individual explanatory variables in Model 2 are very close to those in Model 3, which confirms this last model as most appropriate. Estimated coefficients for the grouped (country-level) variables confirm Hypothesis 1, by showing that the effect of FD differs across areas of government.

\section{Discussion}

Regarding the set of control variables in Model 3, they conform to the view that individual well-being is explained by a comprehensive set of factors [17]. Among results worth mentioning, education appears to contribute more $(\beta=0.467)$ at the tertiary level compared to secondary $(\beta=0.332)$ and primary education $(\beta=0.127)$. Other standard results are the effects of income, age, married 
couple, ideology, and unemployed. Interestingly, more conservative individuals seem to feel more satisfied (IDEOLOGY), as well as catholic and protestants.

As far as our core variable, the debate on the effect of FD encompasses a wide range of areas of public interest that might be affected by giving sub-national governments more leeway to decide $[8,44]$. While better quality public education, more access to health services, housing, recreation, social protection, and public order are all expected to affect SWB positively, we do not know what particular aspects of these services are being improved (worsened) by FD (more of this below). While this research fully subscribes all benefits and caveats from decentralization (Section 1), we know for sure that regardless of the fiscal, administrative, or political autonomy being held by sub-national governments, some areas of economic performance enhance the government's capacity to deliver quality public goods. An important one is the economic growth, whose link to FD has been extensively studied. If FD leads to more growth (e.g., [45]), this raises tax revenues at all levels of government, and in doing so, it potentially improves public goods quality. However controversial [5-7], the effect of DF on growth might be considered an implicit connection between decentralization and specific areas of government.

Our results are in line with those obtained by Bjornskov et al. [13], in that the effect of decentralization on SWB may change in the context of specific public policies. Said result is consistent with a function-specific approach to decentralization [24], as well as evidence suggesting that decentralization in specific areas of government differs across countries with different socio-economic backgrounds [25]. This should be taken as an invitation to further contribute to a wider and mostly unexplored empirical debate on the various specific dimensions of decentralization within broad policy areas. Regardless of the effects being reported, further analysis of even more specific areas of government concern may provide a better understanding of how SWB is affected by Fiscal Decentralization. A separate question hinges upon the way in which public policy outcomes are usually measured and whether these measurements conform to people's subjective perception of the effect of these policies. There is a chance that the multidimensional nature of regular State functions is difficult to capture by a unique and standardized outcome. In this regard, the analysis of the SWB as an endogenous variable does not necessarily confirm previous empirical research based on said standardized measurements of government performance.

The empirical analysis above shows evidence that FD appears to affect SWB positively in the cases of FDRCR (Religion, Culture and Recreation; $\lambda=3.08$ ) and FDHE (Health; $\lambda=0.978$ ). Negative effects are reported in FDED (Education; $\lambda=-1.270$ ) and FDHO (Housing; $\lambda=-1.674$ ), and neutral (non-significant effects) in FDSP (Social Protection). As for Religion, Culture and Recreation, its effect comes to no wonder as this function is mainly a local public good, in which community involvement matters the most. Concerning health services, our results confirm some previous evidence based on standardized indicators (e.g., [46,47]). Nonetheless, people's perception-based study by Anton et. al. [48] on the case of Spain appears to contradict that. Two considerations are in order. On one hand, "information" benefits from FD may be particularly strong in primary health care, where geographic location and local population profiles may require a patient-oriented type of service. On the other, tertiary health services usually underpin standardized procedures and large-scale input acquisitions. Since our data does not differentiate between these two levels, we interpret our results as an average outcome and as further evidence that people assign primary care a high value.

Similarly, our evidence on Education does not confirm some evidence based on standardized measurements of education attainment (e.g., [49,50]). While decentralization may improve education outputs, it might also have some important negative side effects. From the viewpoint of SWB, an important one is the effect on inter-jurisdictional inequality, which has been reported as a relevant caveat of FD among low- and medium-income countries [51]. Very often, decentralization in general, and FD in particular, leads to some type of co-funding of public schools between the central-level and the sub-national jurisdiction in charge, which translates into huge differences in education quality across the country [52]. Since the local government's willingness and available resources to contribute 
may restrict potential benefits from FD, the effect on people's well-being might not be in line with standardized educational attainments. A similar case can be made on housing. Despite preference, matching can be improved though decentralization, territorial inequality might worsen, which is likely to be perceived by residents as a major pitfall. As regards Social Protection (FDSP) and Public Order and Safety (FDPOS), non-significant effects are consistent with general theoretical predictions on the matter. Despite Social Protection entailing an ample range of specific services in which decentralization might exhibit differentiated effects, the broad area of government action intended to enhance equality and reduce poverty is formally considered a pure public good in which the national government is assumed to take responsibility [1]. Yet, specific dimensions of said policy make it difficult to make unambiguous predictions on the effect of FD.

Further insights into our research question can be obtained from Figure 1. This shows random effects $\left(U_{0 m j}\right)$ by country from Model 3 . Some interesting patterns arise. With few exceptions, cases above the zero line are mostly high-income developed countries. The opposite occurs among those below the line. Such a pattern suggests that some non-observable variables may have a role. The influence of history and the process thereby whereby a country's institutions are built are good candidates to be blamed. Said remark opens new avenues of research that go beyond the individual level of analysis. Decentralization is an institutional characteristic of countries, and as such, it may synthesize the effect of numerous political and economic events over time.

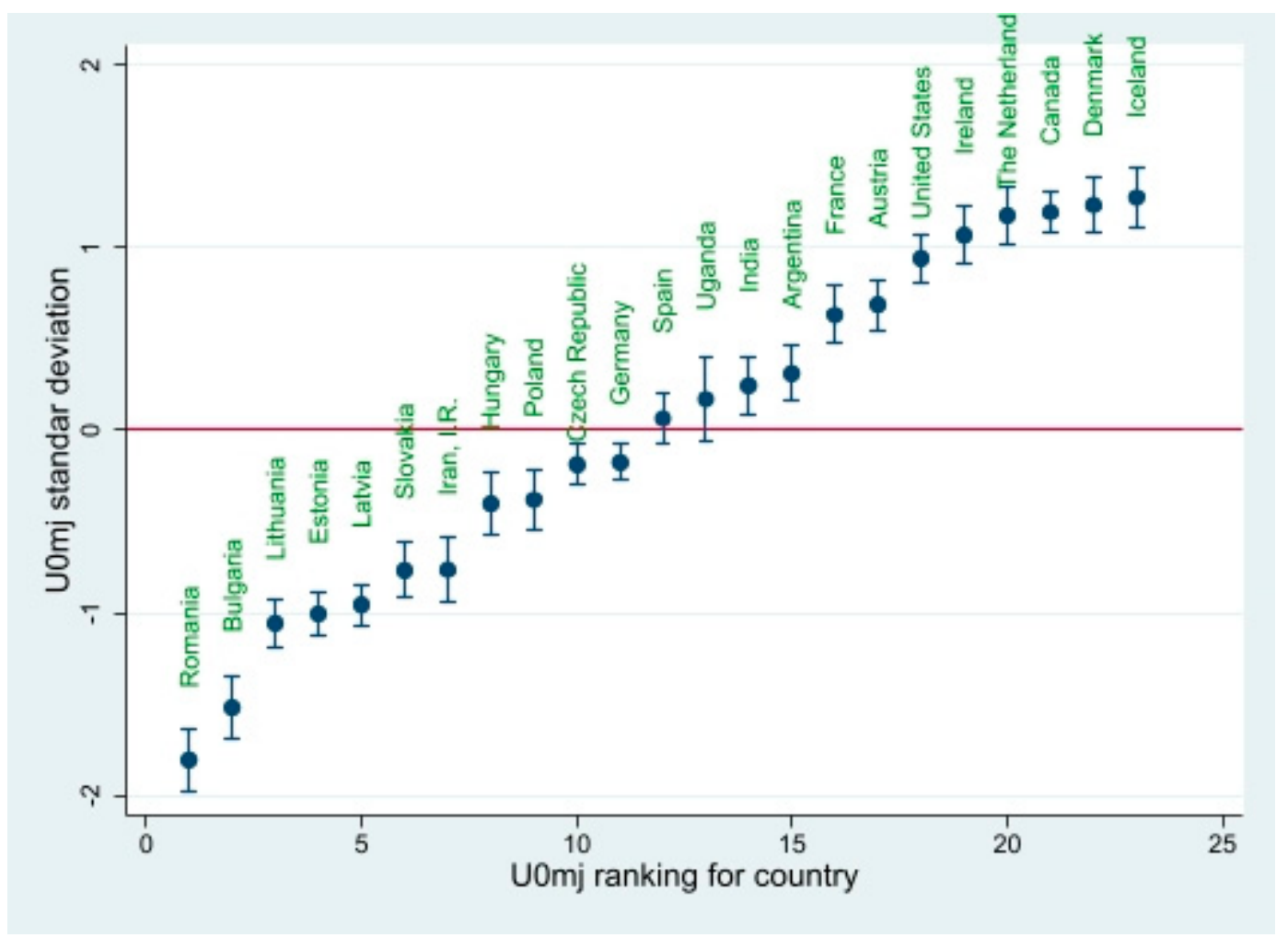

Figure 1. Random effects of country: $U_{0 m j}$.

\section{Conclusions}

This paper's main contribution hinges upon the effect of differentiated expenditure fiscal decentralization on individual well-being. Under the hypothesis that different areas of government are not equally sensitive to the benefits (costs) from decentralization, this present paper examines the case of six different types of FD. We specify a multi-level ordinal logit model with a random intercept and fixed effects. The reason for this is twofold: (i) happiness is a latent variable which is measured through the level of satisfaction declared by individuals; and (ii) there are two types of explanatory 
variables. A set of standard individual variables stand for level 1, and six expenditure FD indicators stand for level 2. Our central hypothesis is that decentralization has a number of benefits and pitfalls. The balance between the two depends on the specific type of government function being considered.

Our main finding is that FD has a differentiated effect on well-being, which confirms the hypothesis above. This expresses in a negative effect from education and housing FD, a positive effect from health and recreation FD, and a non-significant effect from social protection, public order, and transportation FD. While various forms of FD appear to have different effects, this underpins an invitation to further explore even more specific measurements of decentralization. Related relevant questions are referred to what level of government is in charge of paying teachers' salaries, the maintenance of schools and health centers, the design of primary health care policies, local crime prevention, and many other specific features. Under the recognition that different areas of government concern have important specificities, a major conclusion arises from this analysis. This is that general, all-across the board decentralization is no good. A "selective" decentralization approach should be seen as the first-best option. Said policy conclusion is twofold. On one hand, specific decentralization policies have specific effects on individual well-being. On the other, selectiveness should be also extended to the distribution of competences and tax power among same-level jurisdictions within a particular country. A relevant question is whether all departments, provinces, municipalities, and the like should have the same leeway to decide. While this quest is not directly derived from our empirical results, it also follows from the recognition that tax mobilization capacity, as well as management skills to run specific public policies, are usually very unevenly distributed across jurisdictions.

Finally, future avenues of research on the subject matter should address the relevance of more (less) decentralization on even more specific areas of public administration. Decisions over wages being paid, the maintenance of public facilities, the design of school level syllabus, the stress on some primary health services are some examples of how decentralization, in general, is open to a wide and multidimensional range of policy options. As far as FD is concerned, the same question is in order. Shall we decentralize all local tax policies or only some specific ones? Who should be in charge of tax collection? These are only some questions to look upon.

Author Contributions: L.E.L.-S. He synthesized former literature on the subject matter, which includes the revision of existing contributions, and their connection with this research. Discussion of results and main conclusions are a joint work of both co-authors. J.L.S.-L. He conducted the empirical analysis, which includes the collection of data, estimation of the empirical model and interpretation of empirical findings. Discussion of results and main conclusions are a joint work of both co-authors. All authors have read and agreed to the published version of the manuscript.

Funding: This research received no external funding.

Acknowledgments: This work was supported by CONICYT (Scientific and Technological Research Commission (Grant FONDECYT N. 1171464, Chile), the Spanish State Investigation Agency, the Andalusian Government, the University of Granada(A-SEJ-154-UGR18), and I + D + I Projects Operative Program FEDER the Andalusian (PAIDI: P18-TP-4475).

Conflicts of Interest: The authors declare no conflict of interest.

\section{Appendix A. Multilevel Model Specification and Estimation Method}

\section{Appendix A.1. Multilevel Ordinal Logit Model with I Random Intercept and Fixed Effects}

The accumulated probability of the m-category of $S_{i j}$ is:

$$
\operatorname{Pr}\left(S_{i j}>m \mid X_{i j}, Z_{j}\right)=\operatorname{Pr}\left(S_{i j}^{*}>\kappa_{m} \mid X_{i j}, Z_{j}\right)
$$

Substituting (1) in (A1) and operand:

$$
\begin{aligned}
& \operatorname{Pr}\left(S_{i j}>m \mid X_{i j}, Z_{j}\right)=\operatorname{Pr}\left(\beta X_{i j}+\lambda Z_{j}+\varepsilon_{i j}>\kappa_{m} \mid X_{i j}, Z_{j}\right) \\
& =\operatorname{Pr}\left(-\varepsilon_{i j} \leq \beta X_{i j}+\lambda Z_{j}-\kappa_{m} \mid X_{i j}, Z_{j}\right)=\mathrm{F}\left(\beta X_{i j}+\lambda Z_{j}-\kappa_{m}\right)
\end{aligned}
$$


$\mathrm{F}(\cdot)$ is the accumulated distribution. If $\mathrm{F}(\cdot)$ is a logistic accumulated distribution function, then:

$$
\operatorname{Pr}\left(S_{i j}>m \mid X_{i j}, Z_{j}\right)=\frac{\exp \left(\beta X_{i j}+\lambda Z_{j}-\kappa_{m}\right)}{1-\exp \left(\beta X_{i j}+\lambda Z_{j}-\kappa_{m}\right)}
$$

The log-odds of the Equation (A3) is:

$$
\ln \left(\frac{\exp \left(\beta X_{i j}+\lambda Z_{j}-\kappa_{m}\right)}{1-\exp \left(\beta X_{i j}+\lambda Z_{j}-\kappa_{m}\right)}\right)=\beta_{0 m j}+\sum_{l=1}^{L} \beta_{l m j} X_{l i j}+\sum_{r=1}^{R} \lambda_{r m j} Z_{r j}-\kappa_{m}
$$

$\beta_{0 m j}$ is a constant term, $\beta_{1 m j}$ are parameters that measure the effect of the individual variables, $\lambda_{r m j}$ are associated coefficients of grouped variables.

Alternatively, the model (A4) can be written in terms of $S_{i j}^{*}$ :

$$
\ln \left(\frac{\exp \left(\beta X_{i j}+\lambda Z_{j}+\varepsilon_{i j}\right)}{1-\exp \left(\beta X_{i j}+\lambda Z_{j}+\varepsilon_{i j}\right)}\right)=\beta_{0 m j}+\sum_{l=1}^{L} \beta_{l m j} X_{l i j}+\sum_{r=1}^{R} \lambda_{r m j} Z_{r j}+\varepsilon_{m i j}
$$

By nesting I individuals into $j$ groups, $\beta_{0 m j}$ is assumed to vary across these groups. Therefore, we can rewrite $\beta_{0 m j}$ as follows:

$$
\beta_{0 m j}=\beta_{00 j}+U_{0 m j}
$$

$\beta_{00 j}$ the constant term and $U_{0 m j}$ the random effect of $j$ group.

By substituting A6 into A5, we get a multilevel ordinal logit with I random intercepts and fixed effects for the $m$-categories of $S_{i j}$ (A7).

$$
\ln \left(\frac{\exp \left(\beta X_{i j}+\lambda Z_{j}+\varepsilon_{i j}\right)}{1-\exp \left(\beta X_{i j}+\lambda Z_{j}+\varepsilon_{i j}\right)}\right)=\beta_{00 j}+\sum_{l=1}^{L} \beta_{l m j} X_{l i j}+\sum_{r=1}^{R} \lambda_{r m j} Z_{r j}+U_{0 m j}+\varepsilon_{m i j}
$$

By assuming that the effects of $X_{l i j}$ and $U_{0 m j}$ are fixed and random, the following holds:

$$
\begin{gathered}
E\left(\varepsilon_{m i j}\right)=0, \operatorname{Var}\left(\varepsilon_{m i j}\right)=\sigma_{\varepsilon_{m j}}^{2} \\
E\left(U_{0 m j}\right)=0, \operatorname{Var}\left(U_{0 m j}\right)=\sigma_{U_{0 m j}}^{2}
\end{gathered}
$$

where $\sigma_{\varepsilon_{m j}}^{2}$ and $\sigma_{U_{0 m j}}^{2}$ stand for the variance components of the random and fixed effects, respectively.

Appendix A.2. Multilevel Ordinal Logit Model with I Random Intercept and Fixed Effects in Individual Explanatory Variable

Assuming that $Z_{r j}$ does not affect $S_{i j}^{*}$ model (A7) can be written as follows:

$$
\ln \left(\frac{\exp \left(\beta X_{i j}+\lambda Z_{j}+\varepsilon_{i j}\right)}{1-\exp \left(\beta X_{i j}+\lambda Z_{j}+\varepsilon_{i j}\right)}\right)=\beta_{00 j}+\sum_{l=1}^{L} \beta_{l m j} X_{l i j}+U_{0 m j}+\varepsilon_{m i j}
$$

Similar to the multilevel ordinal logit model with I random intercept and fixed effects, the following is confirmed:

$$
E\left(\varepsilon_{m i j}\right)=0, \operatorname{Var}\left(\varepsilon_{m i j}\right)=\sigma_{\varepsilon_{m j}}^{2} E\left(U_{0 m j}\right)=0 y \operatorname{Var}\left(U_{0 m j}\right)=\sigma_{U_{0 m j}}^{2}
$$


Appendix A.3. Multilevel Ordinal Logit Model with I Random Intercept

If we assume that $S_{i j}^{*}$ does not depend on the explanatory variable $X_{l i j}$ and $Z_{r j}$, model (A7) can be rewritten as follows:

$$
\ln \left(\frac{\exp \left(\beta X_{i j}+\lambda Z_{j}+\varepsilon_{i j}\right)}{1-\exp \left(\beta X_{i j}+\lambda Z_{j}+\varepsilon_{i j}\right)}\right)=\beta_{00 j}+U_{0 m j}+\varepsilon_{m i j}
$$

The same as in previous models, the following is confirmed:

$$
E\left(\varepsilon_{m i j}\right)=0, \operatorname{Var}\left(\varepsilon_{m i j}\right)=\sigma_{\varepsilon_{m j}}^{2} E\left(U_{0 m j}\right)=0 y \operatorname{Var}\left(U_{0 m j}\right)=\sigma_{U_{0 m j}}^{2}
$$

\section{Appendix A.4. Estimation Method}

To estimate Model (A4), (A7), and (A10) we use the ML method, which involves important estimation caveats due to the multidimensional numerical integration originated in the high one-dimensionality of the likelihood function [53]. There are two main approaches to deal with this issue in the literature. They are quasi-likelihood methods (PQL) and the approximation of the likelihood function by some numerical method of integration (MQL). While PQL methods are less computationally demanding, they do not directly involve likelihood, as they use a linear Taylor expansion of the inverse link function around current estimates of fixed and random effects. At the same time, PQL estimates are negatively biased if large variance components exist or the distribution of the response variable departs from normality. In this case, we have used the Adaptive Gaussian Quadrature of Gauss approximation of the maximum likelihood, as proposed by Rabe-Hesketh, Skrondal, and Pickles [28], which scales and translates the quadrature points that take into account the properties of the integrand. Newton-Raphson algorithm which is subsequently used to maximize the likelihood function. Estimations have been done using the GLAMM routine.

\section{References}

1. Oates, W.E. Fiscal Federalism; Harcourt Brace Jovanovich: New York, NY, USA, 1972.

2. Lockwood, B. The political economy of decentralization. In Handbook of Multilevel Finance; Edward Elgar Publishing: Cheltenham, UK, 2015.

3. Oates, W.E. Toward a second-generation theory of fiscal federalism. Int. Tax Public Financ. 2005, 12, 349-373. [CrossRef]

4. Weingast, B.R. The economic-role of political-institutions-Market-preserving federalism and economic-development. J. Law Econ. Organ. 1995, 11, 1-31.

5. Davoodi, H.; Zou, H.F. Fiscal decentralization and economic growth: A cross-country study. J. Urban Econ. 1998, 43, 244-257. [CrossRef]

6. Jin, J.; Zou, H.-F. Fiscal decentralization, revenue and expenditure assignments, and growth in China. J. Asian Econ. 2005, 16, 1047-1064. [CrossRef]

7. Martinez-Vazquez, J.; McNab, R.M. Fiscal decentralization and economic growth. World Dev. 2003, 31, 1597-1616. [CrossRef]

8. Letelier, L. Teoría y Práctica de la Descentralización Fiscal; Ediciones UC: Santiago, Chile, 2012.

9. Inman, R.P.; Rubinfeld, D.L. Federalism. In De Geest, Gerrit Bouckaert, Boudewijn. In Encyclopedia of Law and Economics; E. Elgar: Cheltenham, UK, 2000.

10. Prud'Homme, R. The dangers of decentralization. World Bank Res. Obs. 1995, 10, 201-220. [CrossRef]

11. Storper, M. Society, community, and economic development. Stud. Comp. Int. Dev. 2005, 39, 30-57. [CrossRef]

12. Treisman, D. The Architecture of Government: Rethinking Political Decentralization; Cambridge University Press: Cambridge, UK; New York, NY, USA, 2007; pp. 16, 328.

13. Bjornskov, C.; Drehe, A.; Fischer, J.A. On decentralization and life satisfaction. Econ. Lett. 2008, 99, $147-151$. [CrossRef]

14. Diaz-Serrano, L.; Rodriguez-Pose, A. Decentralization, Subjective Well-Being, and the Perception of Institutions. Kyklos 2012, 65, 179-193. [CrossRef] 
15. Diaz-Serrano, L.; Rodriguez-Pose, A. Decentralization and the Welfare State: What Do Citizens Perceive? Soc. Indic. Res. 2015, 120, 411-435. [CrossRef]

16. Diego-Rosell, P.; Tortora, R.; Bird, J. International Determinants of Subjective Well-Being: Living in a Subjectively Material World. J. Happiness Stud. 2018, 19, 123-143. [CrossRef]

17. Dolan, P.; Peasgood, T.; White, M. Do we really know what makes us happy? A review of the economic literature on the factors associated with subjective well-being. J. Econ. Psychol. 2008, 29, 94-122. [CrossRef]

18. Frey, B.S.; Stutzer, A. Happiness, economy and institutions. Econ. J. 2000, 110, 918-938. [CrossRef]

19. Frey, B.S.; Stutzer, A. What can economists learn from happiness research? J. Econ. Lit. 2002, 40, 402-435. [CrossRef]

20. Hessami, Z. The Size and Composition of Government Spending in Europe and Its Impact on Well-Being. Kyklos 2010, 63, 346-382. [CrossRef]

21. Rodriguez-Pose, A.; Tselios, V. Well-being, Political Decentralisation and Governance Quality in Europe. J. Hum. Dev. Capab. 2019, 20, 69-93. [CrossRef]

22. Sujarwoto, S.; Tampubolon, G. Decentralisation and Citizen Happiness: A Multilevel Analysis of Self-rated Happiness in Indonesia. J. Happiness Stud. 2015, 16, 455-475. [CrossRef]

23. Voigt, S.; Blume, L. The economic effects of federalism and decentralization-A cross-country assessment. Public Choice 2012, 151, 229-254. [CrossRef]

24. Letelier, S.L.; Sáez-Lozano, J.L. Fiscal Decentralization in Specific Areas of Government A Technical Note. Econ. Mex. Nueva Época 2013, 22, 357-373.

25. Letelier-Saavedra, L.E.; Saez-Lozano, J.L. Fiscal decentralization in specific areas of government: An empirical evaluation using country panel data. Environ. Plann C 2015, 33, 1344-1360. [CrossRef]

26. Llorca-Rodríguez, C.M.; García-Fernández, R.M.; Sáez-Lozano, J.L. Poverty and fiscal decentralization: An empirical analysis by social policies. Trimestre Económico 2017, 84, 611-643. [CrossRef]

27. Goldstein, H. Multilevel Statistical Models; John Wiley \& Sons: Hoboken, NJ, USA, 2011; Volume 922.

28. Rabe-Hesketh, S.; Skrondal, A.; Pickles, A. Maximum likelihood estimation of limited and discrete dependent variable models with nested random effects. J. Econom. 2005, 128, 301-323. [CrossRef]

29. Raudenbush, S.W.; Bryk, A.S. Hierarchical Linear Models: Applications and Data Analysis Methods; Sage: Newbury Park, CA, USA, 2002; Volume 1.

30. Easterlin, R.A. Does economic growth improve the human lot? Some empirical evidence. In Nations and Households in Economic Growth: Essays in Honor of Moses Abramovitz; David, P., Reder, R., Eds.; Academic Press: New York, NY, USA, 1974.

31. Headey, B.; Krause, P. A Health E Wealth Model of Change in Life Satisfaction: Analysing Links between Objective Conditions \& Subjective Satisfaction; Sonderforschungsbereich 3: Bonn, Germany, 1988.

32. Kapteyn, A.; Vanpraag, B. New approach to construction of family equivalence scales. Eur. Econ. Rev. 1976, 7, 313-335. [CrossRef]

33. Martin, J.K.; Lichter, D.T. Geographic-Mobility and Satisfaction with Life and Work. Soc. Sci. Q. 1983, 64, 524-535.

34. Morawetz, D.; Atia, E.; Bin-Nun, G.; Felous, L.; Gariplerden, Y.; Harris, E.; Soustiel, S.; Tombros, G.; Zarfaty, Y. Income-Distribution and Self-Rated Happiness-Some Empirical-Evidence. Econ. J. 1977, 87, 511-522. [CrossRef]

35. Ng, Y.K. Economic-growth and social-welfare-Need for a complete study of happiness. Kyklos 1978, 32, 575-587.

36. Scitovsky, T. Income and happiness. Acta Oecon. 1976, 15, 45-53.

37. Sirgy, M.J.; Morris, M.; Samli, A.C. The question of value in social marketing use of a quality of life theory to achieve long-term life satisfaction. Am. J. Econ. Sociol. 1985, 44, 215-228. [CrossRef]

38. Wansbeek, T.; Kapteyn, A. Tackling hard questions by means of soft methods-The use of individual welfare functions in socio-economic policy. Kyklos 1983, 36, 249-269. [CrossRef]

39. Ferrer-i-Carbonell, A.; Frijters, P. How important is methodology for the estimates of the determinants of happiness? Econ. J. 2004, 114, 641-659. [CrossRef]

40. Stutzer, A.; Lalive, R. The Role of Social Work Norms in Job Searching and Subjective Well-Being. J. Eur. Econ. Assoc. 2004, 2, 696-719. [CrossRef]

41. Bjornskov, C.; Dreher, A.; Fischer, J.A.V. Formal institutions and subjective well-being: Revisiting the cross-country evidence. Eur. J Polit. Econ. 2010, 26, 419-430. [CrossRef] 
42. Radcliff, B. Politics, markets, and life satisfaction: The political economy of human happiness. Am. Polit. Sci. Rev. 2001, 95, 939-952. [CrossRef]

43. Veenhoven, R. Freedom and happiness: A comparative study in forty-four nations in the early 1990s. In Culture and Subjective Well-Being; Eunkook, M.S., Ed.; The MIT Press: Cambridge, UK, 2000; pp. 257-288.

44. Ahmad, E.; Brosio, G. Does Decentralization Enhance Service Delivery and Poverty Reduction? Edward Elgar Publishing: Cheltenham, UK, 2009.

45. Jalil, A.; Feridun, M.; Sawhney, B.L. Growth Effects of Fiscal Decentralization: Empirical Evidence from China's Provinces. Emerg. Mark. Financ. Trade 2014, 50, 176-195. [CrossRef]

46. Faguet, J.P.; Sanchez, F. Decentralization and access to social services in Colombia. Public Choice 2014, 160, 227-249. [CrossRef]

47. Jimenez-Rubio, D. The impact of fiscal decentralization on infant mortality rates: Evidence from OECD countries. Soc. Sci. Med. 2011, 73, 1401-1407. [CrossRef]

48. Anton, J.I.; de Bustillo, R.M.; Macias, E.F.; Rivera, J. Effects of health care decentralization in Spain from a citizens' perspective. Eur. J. Health Econ. 2014, 15, 411-431. [CrossRef]

49. Letelier, L.; Ormeno, H. Education and fiscal decentralization. The case of municipal education in Chile. Environ. Plan C-Polit. 2018, 36, 1499-1521. [CrossRef]

50. Sanogo, T. Does fiscal decentralization enhance citizens' access to public services and reduce poverty? Evidence from Cote d'Ivoire municipalities in a conflict setting. World Dev. 2019, 113, 204-221. [CrossRef]

51. Rodriguez-Pose, A.; Ezcurra, R. Does decentralization matter for regional disparities? A cross-country analysis. J. Econ. Geogr. 2010, 10, 619-644. [CrossRef]

52. Letelier, S.L.E.; Ormeño, C.H. A quest for Selective Decentralization. In The Case of Municipal Schools in Chile; Instituto de Asuntos Pùblicos: Santiago, Chile, 2020.

53. Jaime-Castillo, A.M.; Saez-Lozano, J.L. Preferences for tax schemes in OECD countries, self-interest and ideology. Int. Polit. Sci. Rev. 2016, 37, 81-98. [CrossRef]

(C) 2020 by the authors. Licensee MDPI, Basel, Switzerland. This article is an open access article distributed under the terms and conditions of the Creative Commons Attribution (CC BY) license (http://creativecommons.org/licenses/by/4.0/). 